\title{
ConcePts of Masculinity ANd Masculinity Studies
}

\author{
TODD W. REESER
}

\begin{abstract}
This essay provides a conceptual history of the study of masculinity in the English-speaking academy from the birth of "men's studies" in the 1980s to current work on global masculinities. With a move away from masculinity as singular toward a focus on multiple masculinities, the influential system of theoretical types of masculinities largely attributed to the work of sociologist R.W. Connell-including especially the concept of "hegemonic masculinity" - set the stage for later work that extended or critiqued the relation between power and categories of masculinities. During this period, sociologists and historians such as Michael Kimmel demonstrated that there was a history of men and masculinity, and that historical crises of masculinity were possible and worthy objects of study. The importance accorded to questions of identities led to a large body of work on the relations between masculinity and homosexuality, women, transgender, race, colonialism, and ethnicity. In what might be considered a branch of masculinity studies that came of age under the influence of Eve Sedgwick, scholars invested in post-structuralist thought or in questions of literary/cultural representation, increasingly considered how masculinity is a complex phenomenon often or always defined by movement and change.
\end{abstract}

As Stefan Horlacher discusses in his introductory article to this volume, literature and masculinity go hand in hand. As a kind of conscious or unconscious fantasy or projection of other worlds, literature can reveal aspects of masculinity that might not come out or be visible in daily life or in other types of cultural artifacts. While it is true that film, painting, sculpture, performance art, and music channel and 
question masculinity and while it is true that literature is in no way the only purveyor of gendered representation, literary form necessarily produces its own unique representation of masculinity, and for this reason, literary analysis in the twenty-first century constitutes a crucial and vibrant wing of masculinity studies. Consequently, many academics and graduate students in the US take it for granted that literary representations of masculinity are a viable and desirable object of intellectual inquiry. In hindsight, it seems inevitable that literary scholars, with their interest in textual subjectivities more broadly, would take up questions around this type of subjectivity too.

But it was not always so. Early work on literary masculinity such as Coppélia Kahn's Man's Estate: Masculine Identity in Shakespeare (1981) and Peter Schwenger's Phallic Critiques: Masculinity and Twentieth-century Literature (1984) broke new ground, proving by example that masculinity could be a viable object of inquiry in the analysis of fiction. ${ }^{1}$ It was, however, Eve Sedgwick's Between Men (1985) that radically changed the terms of both literary studies and gender studies, as "homosocial" became a staple term in the academy. ${ }^{2}$ Despite this important work in literary criticism, the birth of the study of masculinity in the 1980s can be characterized as largely nonliterary in nature, with the social sciences taking the most visible lead in what was then a new and sometimes controversial approach to gender.

Meant to complement Horlacher's Introduction, this article focuses not on the question of the relation between literature and masculinity in theoretical terms, but rather on the actual trajectory of the study of men and masculinity in the English-speaking academy. It traces the trajectory of academic work among both literary scholars and social scientists, revealing both overlaps and disjunctions between the two sets of scholars. As a kind of introduction to the field of masculinity studies, it is intended especially for readers interested in the genealogy of the field of inquiry and in the concomitant history of the articulation of conceptual or theoretical elements around men and masculini-

\footnotetext{
${ }^{1}$ Coppélia Kahn, Man's Estate: Masculine Identity in Shakespeare, Berkeley: University of California Press, 1981; Peter Schwenger, Phallic Critiques: Masculinity and Twentieth-century Literature, London: Routledge and Kegan Paul, 1984.

${ }^{2}$ Eve Kosofsky Sedgwick, Between Men: English Literature and Male Homosocial Desire, New York: Columbia University Press, 1985.
} 
ty, most of which come to inflect readings of literary masculinity today.

In nearly all cases, questions of identity - whether cultural or individual - are central to masculinity studies, meaning that approaches to flesh-and-blood human beings and approaches to literary representations are not fully distinct. Sociological or anthropological understandings of masculinity can be and were in many ways imported to literary studies: literary constructs of masculinity may validate conceptions of gender in the social sciences, but literariness may also transform such conceptions in ways that only take place within the fictional text.

\section{The birth of "men's studies"}

Work on masculinity in the 1980s was often responding, directly or indirectly, to the idea that masculinity was natural or essential, or, in the social sciences, was responding to sex role theory, in which the male sex role was taken as a uniform, stable, and normative configuration to which actual males do or do not conform. In his pioneering book The Myth of Masculinity, the psychologist Joseph Pleck explained that there was at the time no systematic formulation of the male sex role identity paradigm (MSRI). ${ }^{3}$ Although his book aimed to critique that approach to gender, he provided a comprehensive overview of the paradigm in a series of eleven propositions.

The first and most important proposition was: "Sex role identity is operationally defined by measures of psychological sex typing, conceptualized in terms of psychological masculinity and/or femininity

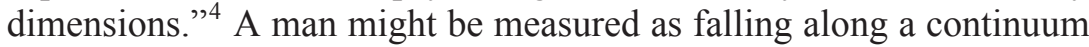
defined by traits or characteristics considered appropriate for his sex, with male traits at one end female traits at the other. ${ }^{5}$ In more complex cases, the unconscious might be part of this measurement, so that a man might be taken to have a conscious masculinity and an unconscious femininity. Or, psychological masculinity and femininity might be taken as independent of each other instead of as opposites on the same continuum (the "dual-unipolar conception", or the "androgynous conception"). But in all of these cases, Pleck points out, "sex-typed characteristics [are] organized along dimensions of psychological

\footnotetext{
${ }^{3}$ Joseph H. Pleck, The Myth of Masculinity, Cambridge, MA: MIT Press, 1981.

${ }^{4}$ Ibid., 16.

${ }^{5}$ Ibid., 17.
} 
masculinity and/or femininity" and they "assume dimensions of the personality experienced by the individual as masculine and/or feminine". ${ }^{6}$ Sex role identity was considered "necessary for good psychological adjustment because of an inner psychological need for it", with homosexuality considered a disturbance of an appropriate identity. ${ }^{7}$ Despite the seeming normativity of the propositions, sex role identity was not natural or God-given, but rather learned behavior (in particular, from adults, parents, and, especially, a parent of the same sex). ${ }^{8}$ Appropriate identity was seen as difficult to develop, especially for black males, and this difficulty could explain boys' trouble in school.

Against an intellectual background that tended to consider gender as singular, scholars increasingly moved to treating masculinity as plural, while not forgetting that it tends to manifest certain recurring characteristics such as homophobia, power, and dominance over women. After presenting the MSRI paradigm, for instance, Pleck took the approach to task, positing an alternative approach to the study of masculinity, termed the sex role strain (SRS) paradigm. His fundamental proposition in this paradigm was: "Sex roles are operationally de-

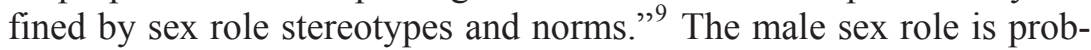
lematic in the sense that traits or qualities taken to define that role are based on shared ideas about what a man is or ought to be. Those definitions are not simple, Pleck explains, but are based in contradiction and inconsistency, and the percentage of men who violate such roles is high. ${ }^{10}$ Since roles change over time, this is another cause of sex role strain. ${ }^{11}$ Pleck's new model thus rejects simple notions of what a man is or should be as definitional of gender, and helps move the study of psychological masculinity toward the idea that the male sex role needs to be imagined as complicated and multiple. For if violation of the male sex role is normal, then that role cannot in fact define any single norm.

As new approaches came to be articulated, gender (even if culturally defined) was not assumed simply to precede human acts, but to be created by them. Consequently, revisioning masculinity as a critical enterprise meant that new types of masculinity could be created aca-

\footnotetext{
${ }^{6}$ Ibid., 18.

${ }^{7}$ Ibid., 21.

${ }^{8}$ Ibid., 19-20.

${ }^{9}$ Ibid., 135.

${ }^{10}$ Ibid., 143-44.

${ }^{11}$ Ibid., 152-53.
} 
demically and pedagogically. A defining moment - perhaps the defining moment - in the move toward multiplicity was the publication of the collection of essays The Making of Masculinities: The New Men's Studies (1987). In his Introduction, the editor Harry Brod (a humanities-based scholar) wrote that the volume is critical of the idea that "all too often, scholars have tended to write too simplistically of the male sex role, rather than the multiplicity of male roles". ${ }^{12}$ As the first chapter of the volume, Joseph Pleck's own essay offered a history of male sex-role identity since $1936,{ }^{13}$ which other authors played off as an outdated approach. Following Pleck's essay, Brod's own essay in the volume, "The Case for Men's Studies", articulated what this new approach to gender might mean. For him, one of the problems in the academy is that "while women's studies corrects the exclusion of women from the traditional canon caused by androcentric scholarship's elevation of man as male to man as generic human, the implications of this fallacy for our understanding of men have gone largely unrecognized".

Brod's volume, then, called for - but also put into practice - an approach to men as gendered beings, and positioned an emerging field of study as "a necessary complement to women's studies". Toward these ends, Brod defined the new men's studies in general terms as "the study of masculinities and male experiences as specific and varying social-historical-cultural formations". ${ }^{14}$ During this time, generally viewed as a second stage in men's studies, scholars increasingly thought through the specificity of masculinities - in time, place, and culture. The volume included essays on a wide variety of topics (for instance, race, athletics, career, myth, biology, male bonding) and from a variety of disciplines (especially sociology, history, literature).

Brod's volume can be taken as a beacon of a new body of research, which included new journals, conferences, and a growing number of publications in the social sciences and humanities on men and masculinities. As a sign that men's studies was reaching a wider audience, an article penned by Brod appeared in 1990 in the American mainstream academic publication The Chronicle of Higher Education un-

\footnotetext{
${ }^{12}$ Harry Brod, Introduction, in The Making of Masculinities: The New Men's Studies, ed. Harry Brod, Boston: Allen and Unwin, 1987, 7 (emphasis in the original).

${ }^{13}$ Joseph H. Pleck, "The Theory of Male Sex-Role Identity: Its Rise and Fall, 1936 to the Present", in ibid., 21-38.

${ }^{14}$ Harry Brod, "The Case for Men's Studies", in ibid., 40 (emphasis in the original).
} 
der the title "Scholarly Studies of Men: An Essential Complement to Women's Studies". ${ }^{15}$

One element of the coming of age of men's studies was the idea that masculinity had to be made visible, to be brought out as an object of study, and to not be considered an unmarked category (in the way that woman or homosexuality as categories were marked and could not easily be ignored or forgotten). Masculinity's traditional invisibility, it was widely thought, was one way in which it maintained its power: by denying implicitly or explicitly that men were gendered, they could escape close scrutiny and resist critique or the need to change. As Antony Easthope wrote: "Social change is necessary and a precondition of such change is an attempt to understand masculinity, to make it visible."16 For this to take place, various questions about masculinity would have to be explicitly asked, including questions about the male body, history, and cultural images. As Michael Kimmel asked in his essay "Invisible Masculinity": "If the pursuit of manhood has been a dominant theme in American history, at least rhetorically and metaphorically, why do American men still have no history?" For him, the response was: "In part because they do not even know what questions to ask." " Of particular importance in making the male body visible as a gendered body was the presence of masculinity on screen, which, consequently, led to an increase in studies of masculinity in film and in the media. ${ }^{18}$

During the period of transition in the 1980s, the study of men and masculinity remained in close dialogue with feminism. In fact, in some cases the line between feminism and masculinity studies was not entirely clear, with volumes such as Alice Jardine and Paul Smith's Men in Feminism (1987) and Joseph Boone and Michael Cadden's

${ }^{15}$ Harry Brod, "Scholarly Studies of Men: An Essential Complement to Women's Studies", Chronicle of Higher Education, 21 March 1990: http://chronicle.com/article/ Scholarly-Studies-of-Men-an/70081/.

${ }^{16}$ Antony Easthope, What a Man's Gotta Do: The Masculine Myth in Popular Culture, Boston: Unwin Hyman, 1990, 7 (emphasis in the original).

${ }^{17}$ Michael S. Kimmel, "Invisible Masculinity", in The History of Men: Essays in the History of American and British Masculinities, ed. Michael S. Kimmel, Albany: State University of New York Press, 2005, 4.

${ }_{18}$ See e.g. Steve Neale, "Masculinity as Spectacle", Screen, XXIV/6 (November 1983), 2-16; Screening the Male: Exploring Masculinities in Hollywood Cinema, eds Steven Cohan and Ina Rae Hark, London: Routledge, 1993; Susan Bordo, "Reading the Male Body", Michigan Quarterly, XXXII/4 (Fall 1993), 696-737. 
Engendering Men: The Question of Male Feminist Criticism (1990). ${ }^{19}$ It was considered crucial that the study of men and masculinity be articulated as part of a feminist project, or as "male feminist criticism". At the same time, an explicit element of the study of men and masculinity came to be a consideration of whether men were in fact co-opting women or feminine positions as a way to outdo or outwit women and, in this sense, issuing a backlash against feminism and the gains of women. Elaine Showalter's essay, titled "Critical CrossDressing: Male Feminists and the Woman of the Year", asks whether male feminism is "a form of critical cross-dressing, a fashion risk of the 1980s that is both radical chic and power play", and considers the question of male appropriation of power in texts such as the film Tootsie, in which a male character cross-dresses and becomes a better woman than the women characters. ${ }^{20}$ Considerations of whether a man who "becomes" a woman (by cross-dressing, by reading as a woman, by appropriating birth, etc.) was re-empowering men were feminist in origin, but this critical approach provided what became (and remains) a current of masculinity studies in which similar critical questions can be asked in configurations in which a man takes on characteristics not generally attributed to him.

The continuing relation between feminism and masculinity meant that, in other cases, scholars were suspicious of mythopoetic or Jungian-influenced attempts to reposition masculinity as essential or natural, to the point that such suspiciousness helped define men's studies in the 1990s. Most famously in an American context, the 1990 publication of Robert Bly's best-selling book Iron John: A Book about Men provoked scholarly discourse that was largely critical of the book. Bly posited some basic myths of manhood through ancient stories and legends, to give birth to a new, vigorous manhood simultaneously centered on emotion. Bly wrote in his Preface that his book "does not seek to turn men against women, not to return men to the domineering mode that has led to repression of women and their values for centuries". He viewed the men's movement as operating "on a separate timetable" from the women's movement, and as not

${ }^{19}$ Men in Feminism, eds Alice Jardine and Paul Smith, New York: Methuen, 1987; Engendering Men: The Question of Male Feminist Criticism, eds Joseph A. Boone and Michael Cadden, New York: Routledge, 1990.

${ }^{20}$ Elaine Showalter, "Critical Cross-Dressing: Male Feminists and the Woman of the Year", in Men in Feminism, 120; see also Tania Modleski, Feminism Without Women: Culture and Criticism in a 'Postfeminist' Age, New York: Routledge, 1991. 
excluding gay men. ${ }^{21}$ Scholars in men's studies from the early 1990 s, however, often responded rather negatively to the book, the book's popularity, and the mythopoetic approach in a larger sense, viewing the book as a challenge to many of the presuppositions about the study of men that they had worked to popularize and as perhaps symptomatic of the continuing need or desire to view masculinity as natural or essential.

Several of the essays in the important volume Theorizing Masculinities were specific in their critiques. ${ }^{22}$ Scott Coltrane, for instance, commented on the "misogynist overtones" of the community conjured up by Bly and critiqued such approaches to gender as reducing "historically and culturally specific myths and practices to universal psychological or biological truths, thereby ignoring the social structural conditions that produced them". "Pierrette Hondagneu-Sotelo and Michael Messner concluded that "the mythopoetic men's movement may be seen as facilitating the reconstruction of a new form of hegemonic masculinity - a masculinity that is less self-destructive, that has revalued and reconstructed men's emotional bonds with each other, and that has learned to feel good about its own Zeus power". ${ }^{24}$ The popularity of these kinds of mythopoetic approaches challenged the profeminist men's movement, and for scholars engaged in men's studies, brought concern that these two movements might be viewed as one and the same. However the mythopoetic movement helped men's studies define itself as an academic movement based not on an essential core of masculinity, but on an assumption of multiple masculinities.

As Brod had suggested in his call for a new men's studies, one element of a paradigm shift was to consider how masculinity had changed over time. To study historical changes of masculinity was to show its plurality. The historian-sociologist Michael Kimmel, one of

\footnotetext{
${ }^{21}$ Robert Bly, Preface, in Iron John: A Book about Men, New York: Random House, 1990, x.

${ }^{22}$ See Scott Coltrane, "Theorizing Masculinities in Contemporary Social Science", in Theorizing Masculinities, eds Harry Brod and Michael Kaufman, Thousand Oaks, CA: Sage, 1994, 39-60; Pierrette Hondagneu-Sotelo and Michael A. Messner, "Gender Displays and Men's Power: The 'New Man' and the Mexican Immigrant Man", in ibid., 200-18; Michael S. Kimmel and Michael Kaufman, "Weekend Warriors: The New Men's Movement", in ibid., 259-88.

${ }^{23}$ Coltrane, "Theorizing Masculinities in Contemporary Social Science", 45.

${ }^{24}$ Hondagneu-Sotelo and Messner, "Gender Displays and Men's Power”, 204.
} 
the best known and prolific scholars of men and masculinity, has published extensively on ways in which masculinity is constructed culturally and historically, especially in the US. In the Introduction to his comprehensive historical study Manhood in America, Kimmel defined the two key elements of writing about men as men: "first, to chart how the definition of masculinity has changed over time; second, to explore how the experience of manhood has shaped the activities of American men." ${ }^{25}$ His approach allowed for examinations of key aspects or morphologies of masculinity, such as "the self-made man". Whereas traditionally women's history was taken as reacting to men's history, the direction of the influence could be reversed, since, in his words, "definitions of masculinity are historically reactive to changing definitions of femininity". ${ }^{26}$ Historians in British history who have worked on men and masculinity include John Tosh, whose work on Victorian England traces key shifts in what it meant to be a man, and in Australian history, Martin Crotty who traces shifts in ideal middleclass masculinity in late-nineteenth and early-twentieth-century Australia. ${ }^{27}$

While this kind of diachronic change might be taken as the domain of history, literary representation, too, charts changing definitions of masculinity. Moderation, for instance, was a key definitional element of early-modern European masculinity, but today in much of the West may be seen quite differently. ${ }^{28}$ A key component of the study of the history of masculinity or of the representation of masculinity is the definition of cultural morphologies that change over time (for example, the courtier, the dandy, the gentleman, the metrosexual), and the question of the unstable relation among similar morphologies across time periods. ${ }^{29}$ The history of masculinity does not have to be studied, however, as morphologies or as a series of traits culturally associated

\footnotetext{
${ }^{25}$ Michael Kimmel, Introduction, in Manhood in America: A Cultural History, New York: Free Press, 1996, 2.

${ }^{26}$ Michael Kimmel, "The Contemporary 'Crisis' of Masculinity in Historical Perspective", in The Making of Masculinities, 123 (emphasis in the original).

${ }^{27}$ John Tosh, A Man's Place: Masculinity and the Middle-class Home in Victorian England, New Haven, CT: Yale University Press, 1999; Martin Crotty, Making the Australian Male: Middle-Class Masculinity, 1870-1920, Carlton South: Melbourne University Press, 2001.

${ }^{28}$ See Todd W. Reeser, Moderating Masculinity in Early Modern Culture, Chapel Hill, NC: University of North Carolina Press, 2006.

${ }^{29}$ See Todd W. Reeser, Masculinities in Theory: An Introduction, Malden, MA: Wiley Blackwell, 2010, 216-26.
} 
with men, but can also be studied as a series of tensions or contradictions within definitions of what a man means, mirroring Pleck's psychological ideas on masculinity as inherently contradictory.

One key strain of approaches to masculinity considers when and why men are in a state of crisis, or considers the socio-historical moments in which definitions of what a man is or should be change. The idea that masculinities change over time, and that certain historical moments are more stressful for men than others became canonical in thinking about historicity. While some took certain historical moments as more crisis-filled than other ones, other scholars viewed masculinity as always, in a certain sense, in a state of crisis and considered that labeling a given period as a crisis assumes that there are other periods when masculinity is somehow free of anxiety or crisis. Crises might be provoked by changes in the status or women or homosexuality, or by cultural shifts in labor, capital, or the nation. Within the area of American cultural studies, Bryce Traister isolated a crisis theory "rooted in a new historiography of American masculinity that locates instability at the base of all masculine identities constructed within American cultural matrices". ${ }^{30}$ As Traister's article suggests, the crisis model of masculinity has inflected historical studies as well as literary criticism. Consequently, what happens in a literary text might be taken to signify not a character's own crisis, but embody a larger cultural crisis resulting from shifts in what masculinity is taken to mean.

\section{Hegemonic masculinity}

Often considered the most influential theoretical concept in the history of the study of men and masculinity, "hegemonic masculinity" is widely attributed to R.W. Connell's seminal book Masculinities (1995). ${ }^{31}$ Tim Carrigan, Bob Connell, and John Lee's earlier essay, "Toward a New Sociology of Masculinity" (1987), however, also discussed the concept at length. Responding to assumptions of masculinity as stable, the three authors defined hegemonic masculinity as "a question of how particular groups of men inhabit positions of power and wealth, and how they legitimate and reproduce the social relation-

\footnotetext{
${ }^{30}$ Bryce Traister, "Academic Viagra: The Rise of American Masculinity Studies", American Quarterly, LII/2 (June 2000), 276.

${ }^{31}$ R.W. Connell, Masculinities, Berkeley: University of California Press, 1995. But see also R.W. Connell, Gender and Power: Society, the Person and Sexual Politics, Stanford, CA: Stanford University Press, 1987; and R.W. Connell, Which Way Is Up? Essays on Sex, Class and Culture, Sydney: Allen and Unwin, 1983.
} 
ships that generate their dominance". In a given culture, even if hegemonic masculinity may not be so common but "may only correspond to the actual characters of a small number of men", nonetheless "large numbers of men are complicit in sustaining the hegemonic model". ${ }^{32}$

Men's dominance over women was central to this definition, but so was the heterosexuality of hegemonic masculinity, at least in most modern cultures. One advantage of this approach to gender, then, was that it married "the gay movement's" and feminist approaches to masculinity by considering that hegemonic masculinity usually situates itself negatively $v i s-\grave{a}-v i s$ both gay men and women. The model also helped make historicity central to de-essentializing masculinity: "'Hegemony' ... always refers to a historical situation, a set of circumstances in which power is won and held. The construction of hegemony is not a matter of pushing and pulling between ready-formed groupings but is partly a matter of the formation of those groupings." 33 In particular, that construction takes place, the authors suggested, through commercial mass media, the gendered division of labor, and the state. These social relations are inextricably linked to the gendered psyche, meaning that the study of hegemonic masculinity should take both socio-historical as well as psychological factors into account.

To study hegemonic masculinity is essentially to employ a relational model predicated on power as the central organizing element of gender. In his book Masculinities, Connell called for considerations not only of diversity in considering masculinities, but also of "the relations between the different kinds of masculinity: relations of alliance, dominance and subordination". ${ }^{34}$ Such relations between types of masculinity are dynamic, not static, and a shift or change with respect to gender entails a corresponding shift or change in definitions of hegemonic masculinity. This approach transformed the study of masculinity in part by disbanding the idea that to study masculinity was to study types or static characteristics of men. Hegemonic masculinity should not be seen, then, as "a fixed character type, always and everywhere the same", but rather as "the masculinity that occupies the

\footnotetext{
${ }^{32}$ Tim Carrigan, Bob Connell and John Lee, "Toward a New Sociology of Masculinity", in The Making of Masculinities, 92.

${ }^{33}$ Ibid., 94 (emphasis in the original).

${ }^{34}$ R.W. Connell, Masculinities, 37 (emphasis in the original).
} 
hegemonic position in a given pattern of gender relations, a position always contestable". ${ }^{35}$

In order to sketch out the key relations in the model, Connell famously lays out four categories: hegemony, subordination, complicity, and marginalization. Taking the idea of hegemony from the Italian political theorist Antonio Gramsci, Connell defines a gendered revision of Gramsci's concept as "the configuration of gender practice which embodies the currently accepted answer to the problem of the legitimacy of patriarchy, which guarantees (or is taken to guarantee) the dominant position of men and the subordination of women". ${ }^{36}$ Hegemonic masculinity in a given context establishes subordinate masculinities, especially but not exclusively male homosexuality. Men who may benefit from gender hegemony, but may not actually meet its criteria, fall into the category of complicity: "Masculinities constructed in ways that realize the patriarchal dividend, without the tensions or risks of being the frontline troops of patriarchy, are complicit in this sense." ${ }^{37}$ Marginalized masculinities are not so much subordinate as much as they are dependent on hegemonic masculinity for authorization. Connell's examples in this category pertain largely to race: "in the United States, particular black athletes may be exemplars for hegemonic masculinity. But the fame and wealth of individual stars has no trickle-down effect; it does not yield social authority to black men generally." While these categories of analysis became widespread in academic studies, they were nonetheless sketchy and meant to be what Connell herself calls "a sparse framework" intended to bring about further study. ${ }^{38}$

The large scope of the concept of hegemonic masculinity meant that it was widely employed as a theoretical model, but also that it was criticized, often because of what it left out. Michael Flood studies the slippage in Connell's own use of the term. It is unclear, he writes, whether hegemonic masculinity represents "a particular configuration of gender practice related to patriarchal authority, or describes whatever type of masculinity is dominant in a given social order". ${ }^{39}$ For

\footnotetext{
${ }^{35}$ Ibid., 76 .

${ }^{36}$ Ibid., 77.

${ }^{37}$ Ibid., 79.

${ }^{38}$ Ibid., 81 .

${ }^{39}$ Michael Flood, "Between Men and Masculinity: An Assessment of the Term 'Masculinity' in Recent Scholarship on Men”, in Manning the Next Millennium: Studies in Masculinities, eds Sharyn Pearce and Vivienne Muller, Bentley, WA: Black Swan
} 
Flood, Connell's linkage between hegemonic masculinity as "cultural ideal" and as "patriarchal gender practice" is problematic since influential representations of masculinity circulating in culture may or may not correspond to practices of masculinity. ${ }^{40}$

Margaret Wetherell and Nigel Edley criticized the model because it does not treat the question of how the four categories "actually prescribe or regulate men's lives". ${ }^{41}$ Taking a discourse-centered approach, they articulate the concepts of "imaginary positions" and "psycho-discursive practices" as linguistic techniques whereby individual men create relations to hegemonic masculinity in everyday interactions with other people. Another recurring critique resided in the idea that the model does not suggest the possibility that a minority or subordinate position can come to influence the hegemonic, but assumes discrete relations between types of masculinities.

For Demetrakis Demetriou, hegemonic masculinity should be taken not as pure, but as hybrid: by virtue of appropriating nonhegemonic elements, it can transform itself "in a very deceptive and unrecognizable way" by appropriating and transforming "what appears counter-hegemonic and progressive into an instrument of backwardness and patriarchal reproduction". ${ }^{42}$ While a man may seek to subordinate women, for instance, he may also incorporate elements of women or femininity into his own hegemonic identity. As was the case in the feminist work discussed earlier, men who cross-dress as women, for instance, may not become subordinate or marginal men at all, but rather reaffirm their status as hegemonic.

Connell's model could be taken as not creating sufficient space for resistance to masculine hegemony by subordinate groups. While Connell emphasizes the constant contestation of hegemonic masculinity, the question of how that contestation takes place or what its results might be is not articulated at much length. Conversely, the question of how women might in fact function as part of hegemonic masculinity

Press 2002, 208; see also Patricia Yancey Martin, "Why Can’t a Man Be More Like a Woman? Reflections on Connell's Masculinities", Gender and Society, XII/4 (August 1998), 473.

${ }^{40}$ Flood, "Between Men and Masculinity", 208.

${ }^{41}$ Margaret Wetherell and Nigel Edley, "Negotiating Hegemonic Masculinity: Imaginary Positions and Psycho-Discursive Practices", Feminism and Psychology, IX/3 (August 1999), 336.

${ }^{42}$ Demetrakis Z. Demetriou, "Connell's Concept of Hegemonic Masculinity: A Critique", Theory and Society, XXX/3 (June 2001), 355 (emphasis in the original). 
except as subordinate is not a major concern in the model, as the male dominance of women is taken as a stable given. Could, for instance, a woman leader or businesswoman in fact be more hegemonic than a man? Challenging the theoretical hegemony of hegemonic masculinity, Eric Anderson allows for the concept of "inclusive masculinity" in contexts in which cultural homophobia is diminished or diminishing. ${ }^{43}$

In a recent essay, Connell and Messerschmidt responded to the lengthy reception of the concept of hegemonic masculinity. For them, two aspects of the early discussion of hegemonic masculinity should be rejected: first, "a single pattern of power, the 'global dominance' of men over women" and, second, the idea that masculinity is "an assemblage of traits" ${ }^{44}$ In their article, they defend the continuing use of hegemonic masculinity in academic work, but they also suggest ways to update and reformulate the concept through expanded thinking about gender hierarchy, geography (including the local, regional, and global), embodiment, and the dynamics of the concept itself.

\section{Race and masculinity}

Hegemonic masculinity relates not only to women and homosexuality, but also to race. Connell had labeled black masculinity in the US as marginal, because, while it may exemplify certain elements of hegemonic masculinity, it is still not recognized, nor can it remain as such, meaning that the whiteness of hegemonic masculinity cannot be ignored. Predating the publication of Connell's Masculinities by more than a decade, Robert Staples' landmark Black Masculinity: The Black Male's Role in American Society, took a conflict theory perspective, positioning black masculinity as inherently oppositional: "As a starting point, I see the black male as being in conflict with the normative definition of masculinity." "Staples defined black men's "dual dilemma": "their subordination as a racial minority has more than cancelled out their advantages as males in the larger society." ${ }^{46}$ Importing

\footnotetext{
${ }^{43}$ Eric Anderson, Inclusive Masculinity: The Changing Nature of Masculinities, New York: Routledge, 2009; see also Mark McCormack, The Declining Significance of Homophobia: How Teenage Boys Are Redefining Masculinity and Heterosexuality, New York: Oxford University Press, 2012.

${ }^{44}$ R.W. Connell and James W. Messerschmidt, "Hegemonic Masculinity: Rethinking the Concept", Gender and Society, XIX/6 (December 2005), 846-47.

${ }^{45}$ Robert Staples, Black Masculinity: The Black Male's Role in American Society, San Francisco, CA: Black Scholar Press, 1982, 2.

${ }^{46}$ Ibid., 7.
} 
the Francophone theorist Frantz Fanon's model of blackness and colonialism in an innovative way, Staples considered African American masculinity as a form of gender colonized through the history of slavery in the US. Yet, his study does not consider masculinity solely as a black man-white man conflict, as it takes homosexuality and relations with women into account as well.

Despite Staples' ground-breaking book, the role of blackness was far from a major concern of work in the 1980s, but since then black or African American masculinity has come to play an increasingly important role in the field. Majors and Billson treat a specific form of black masculinity - the cool pose, "a ritualized form of masculinity that entails behaviors, scripts, physical posturing, impression management, and carefully crafted performances that deliver a single, critical message: pride, strength, and control". ${ }^{47}$ Maurice Wallace's Constructing the Black Masculine participates in a new wave of work post-1994, with the express aim of "bringing race to bear on a crisis theory in order precisely to deny the normativity of those erstwhile deployments". ${ }^{48}$ Part of such a de-normatizing process is to focus not simply on how the black man is represented or relates to hegemonic masculinity, but on the question of how racialized bodies are framed visually. As Wallace explains his subject matter: "enframement ... is the ur-trope of black male specularity for this study."

While blackness might be the most widely considered racial configuration, scholars focusing on race and ethnicity in the Anglophone world have considered how given masculinities are analogically linked with the feminine or with effeminacy, how they relate to hypermasculinity or machismo, and how such analogies break down or do not function. Extending parallels between the primitive and castration in Freud, David Eng analyzes cultural representations of Asian American masculinity as symbolically castrated. His approach, however, is dual as he identifies "not only textual moments in which the Asian American male subject is coerced and held to certain (de)idealized sexual and racial identifications but also instances when these identifi-

\footnotetext{
${ }^{47}$ Richard Majors and Janet Mancini Billson, Cool Pose: The Dilemmas of Black Manhood in America, New York: Macmillan, 1992, 4.

${ }^{48}$ Maurice O. Wallace, Constructing the Black Masculine: Identity and Ideality in African American Men's Literature and Culture, 1775-1995, Durham, NC: Duke University Press, 2002, 6.

${ }^{49}$ Ibid., 8.
} 
cations fail or threaten to break down". ${ }^{50}$ Asian American masculinity has provoked a fair amount of discussion in American studies. ${ }^{51}$ In a different context, Mrinalini Sinha studies gender constructs of Asian men as effeminate during the British empire. ${ }^{52}$ Under the influence of Said's Orientalism, representations of a lacking masculinity in nonwestern men are often taken as viewed through an orientalizing lens by which European hegemony is established via gender. In addition, work on Jewish masculinity treats a variety of questions related to culture, ethnicity, and religion, including its perceived effeminacy and its status as marginalized. ${ }^{53}$ While Latino and Native American masculinity in the US have been discussed with less frequency than black masculinity, Pierrette Hondagneu-Sotelo and Michael Messner put Connell's model of hegemonic/marginalized/subordinated masculinities into dialogue with Mexican immigrant men, Alfredo Mirandé made a case for a profeminist Chicano/Latino men's studies, Richard Rogers studies visual representations of Native American masculinity in the figure of the Kokopelli, and Kathleen Glenister Roberts studied Native Americans and masculinity within the context of war. ${ }^{54}$ Shino

50 David L. Eng, Racial Castration: Managing Masculinity in Asian America, Durham, NC: Duke University Press, 2001, 29.

${ }^{51}$ See, for instance, King-Kok Cheung, "Of Men and Men: Reconstructing Chinese American Masculinity", in Other Sisterhoods: Literary Theory and U.S. Women of Color, ed. Sandra Kumamoto Stanley, Urbana: University of Illinois Press, 1998, 17399; Jinqi Ling, "Identity Crisis and Gender Politics: Reappropriating Asian American Masculinity", in An Interethnic Companion to Asian American Literature, ed. KingKok Cheung, New York: Cambridge University Press, 1997, 312-37; Joon Oluchi Lee, "The Joy of the Castrated Boy", Social Text, XXIII/3-4 (Fall-Winter 2005), 3556.

${ }^{52}$ Mrinalini Sinha, Colonial Masculinity: The "Manly Englishman" and the "Effeminate Bengali" in the Late Nineteenth Century, Manchester: Manchester University Press, 1995.

${ }^{53}$ See e.g. A Mensch Among Men: Explorations in Jewish Masculinity, ed. Harry Brod, Freedom, CA: Crossing Press, 1988; Harry Brod, "Some Thoughts on Some Histories of Some Masculinities: Jews and Other Others", in Theorizing Masculinities, 82-96.

${ }^{54}$ Hondagneu-Sotelo and Messner, "Gender Displays and Men's Power"; Alfredo Mirandé, Hombres y Machos: Masculinity and Latino Culture, Boulder, CO: Westview Press, 1997; Richard A. Rogers, "Deciphering Kokopelli: Masculinity in Commodified Appropriations of Native American Imagery", Communication and Critical/Cultural Studies, IV/3 (September 2007), 233-55; Kathleen Glenister Roberts, "War, Masculinity, and Native Americans", in Global Masculinities and Manhood, eds Ronald Jackson II and Murali Balaji, Urbana: University of Illinois Press, 2011, 141-60. 
Konishi engages with the question of the whiteness of hegemonic masculinity within the context of Australian Aboriginal masculinity. ${ }^{55}$

If masculinity should no longer be taken to be invisible, the same should be said of whiteness as a racial construct. To study white masculinity as racialized and as gendered, then, is to render visible two types of identities often invisible. Analogies between race and gender that privilege white masculinity include muscularity, ${ }^{56}$ and explain, for instance, why bodybuilding may be imagined as a white sport or why muscular heroes such as Tarzan, Hercules, or Rambo are so often white, or perceived as white. Work on race and masculinity grew in other directions as well, as evidenced for instance by the essays collected in Stecopoulos and Uebel. ${ }^{57}$ Discussions of interracial masculinity show, too, how connections or relations between men of diverse races are gendered. With an American tradition of white-black males who love each other - as represented most famously by Huckleberry Finn and the slave Jim - interracial masculinities in US film have been a particular focus of this kind of work. ${ }^{58}$

\section{Complicating masculinity}

Over the course of the 1990s, "masculinity" or "masculinities" as terms increasingly came to replace "men's studies". To take one example, the name of the Men's Studies Review was changed to masculinities in 1993, a change implying that "men's studies" is not a direct reaction against "women's studies". Often, the phrase "men and masculinities" is employed in English to simultaneously allow for links and disjunctures between sex and gender. But the increasing use of the terms "masculinity" or "masculinities" is often thought to suggest that they do not have to be directly or naturally linked with the male body or with men, and that they are complicated and unstable phenomena, not easily pinned down and not necessarily what they appear to be, thus much more than simply the lives of actual men. Many scholars in

\footnotetext{
${ }^{55}$ Shino Konishi, “Aboriginal Masculinity in Howard's Australia”, in ibid., 161-85.

${ }^{56}$ See Richard Dyer, White, New York: Routledge, 1997.

${ }^{57}$ Race and the Subject of Masculinities, eds Harry Stecopoulos and Michael Uebel, Durham, NC: Duke University Press, 1997.

${ }^{58}$ See Donald Bogle, Toms, Coons, Mulattoes, Mammies, and Bucks: An Interpretive History of Blacks in American Films, New York: Continuum, 2001; Melvin Donalson, Masculinity in the Interracial Buddy Film, Jefferson, NC: McFarland, 2006; Brian Locke, Racial Stigma on the Hollywood Screen from World War II to the Present: The Orientalist Buddy Film, New York: Palgrave Macmillan, 2009.
} 
humanities fields such as literature, film, or cultural studies prefer the terms, possibly rejecting "men's studies" altogether, because they suggest a focus on questions of representation. This semantic shift is indicative, too, of other changes in the field, including the move away from an almost exclusive focus on male bodies and the move toward approaches inflected with post-structuralist thought.

The term "masculinity" may emphasize its social-constructedness, and consequently, that it is open to reconstruction. The plural "masculinities" is taken to reflect multiplicity, including those related to race and nation. While some scholars consider the vagueness and expansiveness of masculinity as a positive because it reflects the fact that gender itself is difficult to pin down, for others the shift creates confusion around the seemingly nebulous term or diverts attention from men's gendered practices. ${ }^{59}$ Clatterbaugh suggests some specific semantic confusions in this regard, including incoherencies produced by taking masculinity as discursively constructed. ${ }^{60}$

One way to study how masculinity is not what it appears to be is not to separate masculinity and homosexuality as two separate elements (as hegemonic and marginal for instance), but to consider them as overlapping identities. Men may not make direct reference to homosexuality, but it may nonetheless subtend masculine relations. While homophobia and the objectification of women were both often taken as central defining elements of masculinity in the 1980s, Eve Sedgwick's Between Men (1985) articulated a widely influential model of homosociality that brought together feminist and gay approaches to the study of literary representations of masculinity. Some scholars in literary studies consider it an inaugural book in the move from feminism to gender studies. Sedgwick herself writes that she is "assimilating 'French' feminist - deconstructive and/or Lacanian-oriented feminism - to the radical-feminist end of this spectrum". ${ }^{61}$

While Sedgwick's ground-breaking book made its way into some contemporaneous work in social-science work in men's studies, it is rarely cited or discussed, suggesting a rather strict separation between

59 Jeff Hearn, "Is Masculinity Dead? A Critique of the Concept of Masculinity/masculinities", in Understanding Masculinities: Social Relations and Cultural Arenas, ed. Máirtín Mac an Ghaill, Buckingham: Open University Press, 1996, 20217.

${ }^{60}$ Kenneth Clatterbaugh, "What Is Problematic about Masculinities?", Men and Masculinities, I/1 (July 1998), 24-45.

${ }^{61}$ Sedgwick, Between Men, 11. 
more literary/cultural approaches and social science ones, even as Sedgwick's work resembled that of other scholars in that it aimed to incorporate both feminist and gay approaches. Based partially on anthropological theory, Sedgwick's study posits that the relation between two seemingly heterosexual men and certain relations of desire between men and women should not be considered separate. Two men might desire the same woman as a way to displace the possibility of homoerotic desire for each other, meaning that the stronger interpersonal relation is not the heterosexual one, but that between the two men. That male-male relation, with patriarchal undertones, suggests that men are sharing power as much as desire through the objectification of the women mutually desired. Behind the triangular model of desire lies the presupposition that male-male relations are located on a continuum of desire that ultimately cannot locate or cannot stabilize male-male relations as strictly "heterosexual". As she writes: "To draw the 'homosocial' back into the orbit of 'desire,' of the potentially erotic ... is to hypothesize the potential unbrokenness of a continuum between homosocial and homosexual." ${ }^{\text {"2 }}$ Her notion of a continuum of desire mirrored previous work in feminist thought that considered women's relation with women on a continuum of desire, and disbanded the over-simple idea that women's sexuality is fluid while men's is not.

As a result of Sedgwick's book, the words "homosocial" and "homosociality" became widely used in the study of men and masculinity, as male-male interactions - even when two men do not specifically desire the same women - are taken to fall on a continuum of male homosocial desire and as the instability of men's interactions makes it difficult to term them purely heterosexual. The role of female homosociality is hardly discussed in Between Men, and Sedgwick herself calls for more work on "the relations between female-homosocial and male-homosocial structures". ${ }^{63}$ In addition, the question of whether her model could be taken to apply to non-European cultures is one that she raises: "any attempt to treat [this book's formulations] as crosscultural or (far more) as universal ought to involve the most searching and particular analysis." ${ }^{64}$ In terms of the analytic practice of masculinity, Sedgwick makes a case for thinking in sophisticated ways about

\footnotetext{
${ }^{62}$ Ibid., 1.

${ }^{63} \mathrm{Ibid} ., 18$

${ }^{64}$ Ibid., 19.
} 
representation as integral to the way in which power functions: "Before we can fully achieve and use our intuitive grasp of the leverage that sexual relations seem to offer on the relations of oppression, we need more - more different, more complicated, more diachronically apt, more off-centered - more daring and prehensile applications of our present understanding of what it may mean for one thing to signify another." ${ }^{65}$ From her first textual reading of Shakespeare's Sonnets to her last one on Charles Dickens' The Mystery of Edwin Drood, historicity and contextualization are central to reading homosociality, leaving open the adaption of her approach to other time periods that she does not specifically treat.

With her focus on interpretive complexity in the representation of gender relations, Sedgwick sets the stage to consider movementcentered approaches to masculinity, including the queerness within heterosexual masculinity. If one of the presuppositions of queer theory is that male homophobia is attempting to expel the abject queer from within, then there is necessarily something queer about or within masculinity in the first place. Or, alternately, excessive forms of masculinity may point to an instability of masculinity that contains something queer. An anti-normative gender presentation, the hypersexual man, for instance, may act the way he does because he is attempting to expel, or is responding to, an anxiety of queerness within.

If heterosexual masculinity can be taken as queer in some sense, it can also be taken as "performative". Judith Butler famously articulates the idea that gender is performative in her ground-breaking Gender Trouble. ${ }^{66}$ While the book focuses on gender and not masculinity specifically, her theoretical concepts can be brought to bear on masculinity in productive ways, ${ }^{67}$ and have had an immense influence on masculinity studies, particularly in the humanities. Butler famously suggests that the traditional distinction between sex and gender is no distinction at all, but that gender should be taken as "the very apparatus of production whereby the sexes themselves are established". ${ }^{6}$ In this sense, then, "maleness" or "manhood" in its biological configuration (as influenced by testosterone, the male sex drive, or the penis,

\footnotetext{
${ }^{65}$ Ibid., 11 .

${ }^{66}$ Judith Butler, Gender Trouble: Feminism and the Subversion of Identity, New York: Routledge, 1990.

${ }^{67}$ See Reeser, Masculinities in Theory, Chapter 3.

${ }^{68}$ Butler, Gender Trouble, 7.
} 
for instance) can be understood as elements of gender as constructed through the medium of language. It is not testosterone itself that makes a man, but how we understand this element of biology or what we make of it. The male body (like the sexed body in a larger sense) does not have inherent meaning, except as we ascribe meaning to it. In this sense, as per Butler's ideas in Bodies that Matter, ${ }^{69}$ men have to "assume" their maleness. They both take it on and take it for granted. In addition, men are not acting masculine because of something in their genes or in their blood, but by virtue of the fact that their gendered acts implicitly refer to or cite innumerable actions that others have already undertaken - actions that provide authority, meaning, and stability for the current act. So the masculinity of a given cowboy in a film is supported and made possible by an entire host of links between masculinity and space, the frontier, guns, etc. that have been previously made and repeated. From a Butlerian approach, masculinity can be considered as a "corporeal style", ${ }^{70}$ not unchanging and open to change over an individual's life or over a historical time period.

In parallel with the post-structuralist commonplace that signifier and signified do not naturally correspond, the term "masculinity" no longer has to be taken with respect to its supposedly natural receptacle, the male body. While almost all early work on masculinity focused on masculinity and the male body, American studies scholar Judith "Jack" Halberstam's influential book Female Masculinity broke new ground by arguing that a full understanding of masculinity requires that we include considerations of it as separate from the male body: "far from being an imitation of maleness, female masculinity actually affords us a glimpse of how masculinity is constructed as masculinity." ${ }^{71}$ This argument is part of a larger claim that masculinity "becomes legible as masculinity where and when it leaves the white male middle-class body". ${ }^{72}$ For Halberstam, then, it is necessary to maintain "a degree of indifference to the whiteness of the male and the masculinity of the white male and the project of naming his power" and to consider male masculinity as a "counterexample to

\footnotetext{
${ }^{69}$ Judith Butler, Bodies that Matter, New York: Routledge, 1993.

${ }^{70}$ Butler, Gender Trouble, 139.

${ }^{71}$ Judith Halberstam, Female Masculinity, Durham, NC: Duke University Press, 1998, 1 .

${ }^{72}$ Ibid., 2.
} 
the kinds of masculinity that seem most informative about gender relations and most generative of social change". ${ }^{73}$

But if female masculinity should be integral to the study of gender, Halberstam is asking, then why has female masculinity not been an object of study? In the same way that cultural discourses may render female masculinity a non-ideal gender presentation that should not exist, scholars of (male) masculinity may have been participating in an academic discourse in which masculinity can only be male. While Halberstam's book begins to fill the lacuna in the field, this lack in masculinity studies has still not been sufficiently filled, ${ }^{74}$ particularly with respect to heterosexual female masculinities. Aiming to position female masculinity as a diachronic phenomenon that should be integrated into histories of masculinity, Halberstam also established a methodology (termed "perverse presentism") by which previous morphologies of female masculinity can be studied.

If a complete study of masculinity must consider the role of women, the same must be said with respect to disabled, gay male, and transgender subjects. Analogies might be made between disability and lack of masculinity, or conversely between ability and masculinity, but more complicated relations between disability and masculinity might also obtain. ${ }^{75}$ Similarly, gay male masculinities have a varying relation to masculinity, and should be taken in their plurality. ${ }^{76}$ The historically recent notion that male homosexuality is closely connected to effeminacy is challenged in part by considering a range of gender presentations among gay men, including the rejection of effeminacy in favor of gay hegemonic masculinity and racial homosexualities. Gay male masculinity might also be taken as an oscillation between hegemonic and non-hegemonic positions, as dependent on situation, with the closet, passing, and "straight acting" as key elements of such a consideration.

\footnotetext{
${ }^{73}$ Ibid., 3.

${ }^{74}$ But in the literary realm, see Jean Bobby Noble, Masculinities without Men? Female Masculinity in Twentieth-Century Fictions, Vancouver: University of British Columbia Press, 2004.

${ }^{75}$ See Gill Valentine, "What It Means to be a Man: The Body, Masculinities, Disability", in Mind and Body Spaces: Geographies of Disability, Illness, and Impairment, eds Ruth Butler and Hester Parr, London: Routledge, 1999, 167-80; Nicole Markotić and Robert McRuer, "Leading with Your Head: On the Borders of Disability, Sexuality, and the Nation", in Sex and Disability, eds Robert McRuer and Anna Mollow, Durham, NC: Duke University Press, 2012, 165-82.

${ }^{76}$ See Peter M. Nardi, Gay Masculinities, Thousand Oaks, CA: Sage, 2000.
} 
Recent work in transgender studies rethinks masculinity from a new perspective barely acknowledged in the 1980s and 1990s. One of the major sections in the field-defining The Transgender Studies Reader focuses of transgender masculinities. ${ }^{77}$ Taking transgender into account means that masculinity cannot a priori be taken as natural or as the strict province of men, at least in the traditional sense of the word. That a woman can transition and be considered or pass as a man implies that the signifier "masculinity" does not correspond in any direct or natural way to a given signified. Perhaps more radically, if transgender is taken as a transition toward movement itself, not as a change from one discrete sex to another, then the trans body might destabilize stable definitions of masculinity by inventing new gendered configurations. Transgender as an analytic category forces a reconsideration of hegemonic masculinity as well. To transition to becoming a man might (re)affirm the desirability of hegemonic masculinity or, on the other hand, might permit it to be destabilized from within (as a man who challenges gender hegemony). Trans or drag king performance may also question assumptions of male biology as the basis of masculinity. ${ }^{78}$ Female-to-male transgender subjects may or may not challenge masculine hegemony, and if they believe that testosterone creates maleness, may envision sex in a non-Butlerian way as biological. In short, as Henry Rubin writes: "Transgender men have the potential to generate either alternative or hegemonic forms of masculinity." "79 Jason Cromwell discusses the cases of transmen who queer masculinity by revamping cultural discourses to construct a transidentity that can be conveyed to or understood by others. Further, the notion of a masculinity continuum (often thought of as masculinity opposed to femininity, or homosocial opposed to homoerotic) can be reconsidered in light of transgender. ${ }^{80}$ The sometimes very fluid borderline between butch and female-to-male transgender permits con-

\footnotetext{
${ }^{77}$ See The Transgender Studies Reader, eds Susan Stryker and Stephen Whittle, New York: Routledge, 2006.

${ }^{78}$ See Diane Torr and Stephen Bottoms, Sex, Drag, and Male Roles: Investigating Gender as Performance, Ann Arbor, MI: University of Michigan Press, 2010.

${ }^{79}$ Henry Rubin, Self-Made Men: Identity and Embodiment among Transsexual Men, Nashville, TN: Vanderbilt University Press, 2003, 145.

${ }^{80}$ Jason Cromwell, "Queering the Binaries: Transsituated Identities, Bodies, and Sexualities", in The Transgender Studies Reader, 509-20.
} 
siderations of the fluidity of masculinity itself, and of the value attached to sex and masculinity in butch and trans subjects. ${ }^{81}$

If some work takes for granted that the unstable signifier masculinity has no natural referent, it may also assume that masculinity is constituted through complicated forms of representation. Most of this work comes not out of social sciences, but out of the humanities, and is often directly or indirectly subtended by post-structuralist thought. An early example of theoretically-informed work, Victor Seidler's Rediscovering Masculinity took a discourse-centered perspective to masculinity and aimed in part to "reclaim language as a facet of experience". ${ }^{82}$ Under the influence of the French philosopher Jacques Derrida's notions of deferral, some thinkers cast masculinity as an unending, ultimately un-definable phenomenon, composed not so much of social constructs per se but of an unending series of questions. As the cultural critic Homi Bhabha writes in an essay on masculinity: "my own masculinity is strangely separating from me, turning into my shadow, the place of my filiation and my fading. My attempt to conceptualize its conditionality becomes a compulsion to question it." 83 My own Masculinities in Theory takes a systematic and comprehensive approach to masculinity as movement-centered, not as a fixed object of inquiry, and discusses how select post-structuralist theories that do not take masculinity as an object of inquiry can nonetheless be brought to bear on its analysis. Although, for instance, the French philosopher Michel Foucault's theoretical models on power and discourse do not refer to masculinity per se, and have been considered with respect to women, homosexuality, and other non-hegemonic categories, masculinity can be taken in Foucauldian terms as discursively constructed. ${ }^{84}$ One can argue that there is no original form of masculinity, and that its inherent diffuseness means that it cannot ultimately be located in a single place and that it needs to be considered as a fragmented phenomenon a priori. Work on masculine anxiety is also, in a different way, part of a movement-centered approach since it

${ }^{81}$ See Halberstam, Female Masculinity, Chapter 5; Gayle Rubin, "Of Catamites and Kings: Reflections on Butch, Gender, and Boundaries", in The Transgender Studies Reader, 471-81.

${ }^{82}$ Victor J. Seidler, Rediscovering Masculinity: Reason, Language, and Sexuality, London: Routledge, 1989, 5.

${ }^{83}$ Homi K. Bhabha, “Are You a Man or a Mouse?”, in Constructing Masculinity, eds Maurice Berger, Brian Wallis and Simon Watson, New York: Routledge, 1995, 58.

${ }^{84}$ See Reeser, Masculinities in Theory, 29-35. 
assumes masculinity has to respond, perhaps constantly, to anxiety in order to be, or to give the impression of being, stable and static. ${ }^{85}$

While there is often an academic split between these kinds of movement-centered approaches and social-science approaches in men's studies, the former approaches are politically engaged in the sense that they attempt to upend the perception of masculinity as universal and stable and allow for numerous other possibilities. If inherently unstable, hegemonic masculinity cannot maintain its dominance or the perception of dominance. As David S. Gutterman writes in his outline of postmodern interrogations of masculinity: "Postmodern theories of subjectivity, identity, and agency ... can be useful not only for rethinking governing cultural values but also as a framework for actively seeking social change." ${ }^{\prime 86}$ In his discussion, Gutterman makes a case for such approaches to be considered in political coalition building, which depends on gathering fractured constituencies together for a common goal: "the appreciation of difference enables a coalition ... not to try to figure out what $a$ new cultural script for masculinity ought to be. Instead, the coalition could focus on destabilizing and denaturalizing the scripts in place and create the space for a variety of different masculinities to be performed." ${ }^{, 87}$

If stable or movement-centered approaches are, however, taken as antithetical to each other, a possible compromise position between them would be to consider that the experience of masculinity (and of gender in a larger sense) is predicated on a movement between stability or essentialism on the one hand, and free play on the other. ${ }^{88}$ While masculinity itself may be essential or fluid, the experience of masculinity on a daily basis likely oscillates between the sense that it has a core or is natural, and the sense that it is fluid or fragmented. Or, as I have discussed with respect to what I call "a moderate approach to masculinity": "The essentialism that I experience might also place me

\footnotetext{
${ }^{85}$ See also Calvin Thomas who takes the writing of the male body as his topic, arguing that "the mechanisms of assuagement are ideologically embedded in cultural modes of representational containment that govern and restrict the visibility of male bodies and male bodily productions" (Calvin Thomas, Male Matters: Masculinity, Anxiety, and the Male Body on the Line, Urbana: University of Illinois Press, 1996, 3).

${ }^{86}$ David S. Gutterman, "Postmodernism and the Interrogation of Masculinity", in Theorizing Masculinities, 224.

${ }^{87}$ Ibid., 234.

${ }^{88}$ Eve Kosofsky Sedgwick, “'Gosh, Boy George, You Must Be Awfully Secure in Your Masculinity!'”, in Constructing Masculinity, 18.
} 
in a position in which essentialism is not exactly opposed to free play since essentialism might actually help me to understand that free play better." Or conversely, "because I focus on my masculinity as freefloating and non-essential, I might have moments in which I feel masculinity as a core". ${ }^{89}$ While a substantial body of work that takes such a moderate approach and seeks to destabilize the split between stability or essentialism and free-play has yet to appear, this theoretical approach gestures toward a theoretical apparatus that has the potential better to link together humanities-based and other types of work.

\section{Anthropology and the global turn}

A recent, growing body of research gestures toward a key future direction in the study of masculinity, namely the global and the transnational. In 1990, patterns of masculinity within the context of cultural difference were already the focus of anthropologist David Gilmore's Manhood in the Making: Cultural Concepts of Masculinity. Taking into account a number of western and non-western cultures, he studies what it means to be a man or to be a "real man" in selected cultures. The "regularity" that interests him "is the often dramatic ways in which cultures construct an appropriate manhood - the presentation or 'imaging' of the male role". 90 Among his material-based conclusions is the idea that "Manhood is the social barrier that societies must erect against entropy, human enemies, the forces of nature, time, and all the human weaknesses that endanger group life". ${ }^{91}$ A groundbreaking and innovative book at the time of its publication, Gilmore's book was subsequently viewed by some as lacking sufficient plurality in its view of masculinity. In his survey of anthropological approaches to masculinity up until the mid-1990s, Don Conway-Long, for instance, comments on Gilmore's failure to recognize "the plurality of masculinities within any of the cultures he analyzed". ${ }^{92}$ As Conway-Long also suggests, the anthropological work of Gilbert Herdt from the 1980s on South-Pacific-islander cultures and initiation ceremonies could be taken as part of the history of anthropological approaches to masculin-

\footnotetext{
${ }^{89}$ Reeser, Masculinities in Theory, 51.

${ }^{90}$ David D. Gilmore, Manhood in the Making: Cultural Concepts of Masculinity, New Haven: Yale University Press, 1990, 11.

${ }^{91}$ Ibid., 226.

92 Don Conway-Long, "Ethnographies and Masculinities", in Theorizing Masculinities, 61 (emphasis in the original).
} 
ity ${ }^{93}$ even if Herdt's work is not necessarily often imagined in that trajectory.

Despite the growing body of work on non-western masculinities, as Ronald Jackson II and Murali Balaji write, "masculinity studies has generally been ghettoized by a Eurocentric paradigm of whiteness and its Others, the latter most closely associated with the representations and assumed practices of black masculinity". ${ }^{94}$ Scholars are, however, increasingly working on how masculinity is constructed in cultures around the globe, but they are also increasingly interested in how masculinities travel or transition from one cultural zone to another.

Connell calls for work on global masculinities, and sketches out three major types of globalizing masculinity: masculinities of conquest and settlement, masculinities of empire, and masculinities of postcolonialism and neoliberalism. ${ }^{95}$ The small amount of work on the topic largely relates to transnational business or corporate masculinity or to global politics and militarism. Christine Beasley rethinks hegemonic masculinity for consideration of a global context, one aspect of her argument being that the term should focus "on its meaning as a political mechanism involving the bonding together of different masculinities in a hierarchical order". ${ }^{96}$ One might consider what happens to an Asian form of hegemonic masculinity when it encounters an African form, for example. Beasley also calls for thinking about "plural hegemonic masculinities" in a global context with "the language of 'supra' and 'sub' hegemonic" that allow for a range of masculinities to be placed in global dialogue. ${ }^{97}$ Connell and Messerschmidt call for hegemonic masculinities to be studied at the local, regional, and global level, but also to take the links between the three levels into account. ${ }^{98}$ As the world continues to become increasingly global and as the study of masculinity follows suit, scholars are likely to imagine what specific interactions between spatially-defined masculinities will

${ }^{93}$ Ibid., 66-70.

${ }^{94}$ Ronald Jackson II and Murali Balaji, Introduction, in Global Masculinities and Manhood, 21.

${ }^{95}$ R.W. Connell, "Masculinties and Globalization", Men and Masculinities, I/1 (July 1998), 12-16; see also Connell in this volume.

${ }^{96}$ Christine Beasley, "Rethinking Hegemonic Masculinity in a Globalizing World", Men and Masculinities, XI/1 (October 2008), 99.

${ }^{97}$ Ibid., 100.

${ }^{98}$ Connell and Messerschmidt, "Hegemonic Masculinity”, 849. 
take place, and in turn how those interactions will wash back onto the study of gender itself. ${ }^{99}$

99 This article is a shortened and thoroughly reworked version of Todd Reeser, "Englischsprachige Männlichkeitsforschung", in Handbuch Männlichkeit, eds Stefan Horlacher, Bettina Schötz and Wieland Schwanebeck, Stuttgart: Metzler, forthcoming. 